\title{
RECONSIDERING OPEN BORDERS: AN ANALYSIS OF MIGRATION AND GLOBAL
} INEQUALITY

By

Candace Westman, BA, University of Guelph, 2012

\author{
A Major Research Paper \\ presented to Ryerson University
}

in partial fulfillment of the requirements for the degree of

\author{
Master of Arts \\ in the Program of \\ Immigration and Settlement Studies
}

Toronto, Ontario, Canada, 2013

(C) Candace Westman 2013 


\section{AUTHOR'S DECLARATION FOR ELECTRONIC SUBMISSION OF A MAJOR RESEARCH PAPER (MRP)}

I hereby declare that I am the sole author of this Major Research Paper. This is a true copy of the MRP, including any required final revisions, as accepted by my examiners.

I authorize Ryerson University to lend this MRP to other institutions or individuals for the purpose of scholarly research.

I further authorize Ryerson University to reproduce this MRP by photocopying or by other means, in total or in part, at the request of other institutions or individuals for the purpose of scholarly research.

I understand that my MRP may be made electronically available to the public.

Candace Westman 


\title{
RECONSIDERING OPEN BORDERS: AN ANALYSIS OF MIGRATION AND GLOBAL INEQUALITY
}

\author{
Candace Westman \\ Master of Arts 2013 \\ Immigration and Settlement Studies \\ Ryerson University
}

\begin{abstract}
As a result of the neoliberal ideological turn the past few decades have seen a vast liberalization of markets for capital and commodities. Paradoxically, the liberalization of international borders for capital has occurred alongside a restriction of mobility for human beings. Scholarship surrounding migration generally focuses on formulating recommendations for improving the immigration system. Few scholars have focused their attention on questioning the foundational premises of this system. This paper engages with the literature on open borders. It examines the ways in which international borders simultaneously produce and maintain global inequality. It will argue that discussions of liberalizing borders can only take place in the context of a discussion about how to remove those factors that prompt migration in the first place. Studies of migration must be embedded within the broader debates surrounding the political economy of globalization and its impacts on international development.
\end{abstract}

Key Words: Open Borders, Migration, Neoliberalism, Globalization, Global Inequality, Capitalism 


\section{ACKNOWLEDGEMENTS}

I would first like to thank my supervisor, Dr. Tariq Amin-Khan for his thoughtful guidance and support throughout the writing process. I would also like to thank Dr. Harald Bauder for his insight and feedback, particularly under such tight timelines.

I am grateful for my patient editors, Jenna Toppan and Erin Westman as well as to my friends and peers for engaging me in discussions surrounding this topic and for providing relief from the stress of this endeavor.

Finally, I would like to express endless gratitude to my parents for their unwavering support, encouragement, and expectations. Without which I would not be the person I am today. 


\section{TABLE OF CONTENTS}

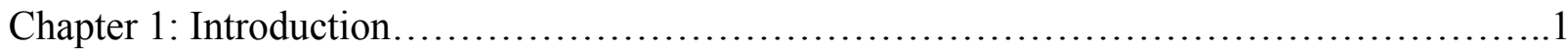

Chapter 2: Methodology .....................................................

Chapter 3: Literature Review..................................................... 10

Chapter 4: Factors that Drive the Migratory Process.................................... 17

Neoclassical Explanations of Migration....................................... 18

Social Structures........................................................ 22

Racialization, Xenophobia, and Cultural Distinction ...........................24

Chapter 5: the Link between Migration and Development.................................28

Neoliberalism and Capitalist Restructuring..................................29

Remittances........................................................ 34

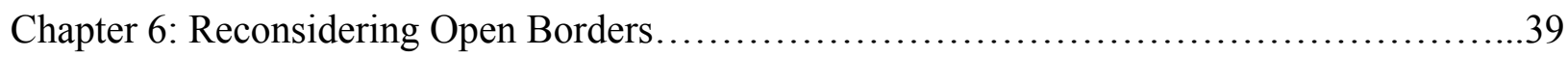

Towards a Universal Management of Migration...............................44

Chapter 7: Conclusion...........................................................4 47

References................................................................. 49 
"As the world draws closer together in the wake of remarkable technical, market and political developments, it is being pulled apart by growing inequalities"- Moses, 2006:19

\section{CHAPTER 1: INTRODUCTION}

Migration is inherently linked to human existence. Humans have been on the move since our first ancestors originated in Eastern Africa (Hall and Kardulias, 2010: 26, Hayter, 2004: 8). Successive waves of migration as a consequence of mercantilist trade and then capitalist development have shaped modern nation-states and created international borders, as we know them today. The majority of the world's developed countries have become diverse, multiethnic societies, and those that have not yet reached this stage are undeniably moving in that direction. People migrate for a variety of reasons. Some migrations are voluntary, in the sense that people migrate to conquer and colonize new territories, or to improve economic well-being and prospects for employment. Many migrations are also forced, including as those who were brought to the Americas and the Caribbean as slaves or indentured labourers, or migrated as asylum seekers fleeing war or persecution in their home country. The growth of the New World can be attributed to the forced efforts of imported migrant labour (Moses, 2006: 44). Today, it is

often difficult to distinguish between forced and voluntary migration. Often the numerous factors that culminate in the decision to migrate blur the line between forced and voluntary. The total estimated number of international migrants worldwide is 214 million persons (UN DESA, 2009). Yet figures of international migration make up only a fraction of movement taking place in the form of internal or regional migration. 
Among states in the Global North, a popular consensus has begun to emerge that the modern era represents unprecedented levels of migration resulting in a "crisis of migration". Alarmist conservative media in the Global North, who perpetuate images of "tidal waves" and "floods" of "parasitic" migrants arriving from the Global South, has perpetuated the discourse of this so-called "crisis". While it is true that the total number of international migrants has more than doubled since 1960 (from 76 million to currently about 175 million) this statistic must be considered alongside the fact that the world population has also doubled from 3 billion in 1960 to 6 billion in 2000. Therefore, international migrants represent only $2.9 \%$ of the world population compared with $2.5 \%$ in 1960 (Bush, 2007:50). Rising to 3.1\% of the total world population in 2008 , the percentage of migrants has remained relatively stable as a share of the total world population (UN DESA, 2009). This raises the question of whether such figures actually indicate a "crisis of migration" as politicians and prominent media sources in the Global North have suggested, or whether this "crisis" is merely the result of changed perceptions towards international migration (Castles, 2004: 857).

The distribution of migrants amongst diverse host societies also varies greatly. Those countries hosting the highest percentage of migrants include Qatar (87\%), United Arab Emirates (70\%), Jordan (46\%), Singapore (41\%), and Saudi Arabia (28\%). In comparison, international migrants make up only $14.2 \%$ of the total population in all of North America, with refugees representing a mere $1.5 \%$ of international migrants (UN DESA, 2009). But statistics fail to tell the full story. They fail to capture the increasing complexity and changing configuration of contemporary migration (Ghosh, 2000:8).

As a result of neoliberal ideologies, the past few decades have witnessed a vast liberalization of world markets for a variety of goods and services. The ideology of liberalism 
can be traced back to the Industrial Revolution in 1760 that gave rise to industrial capitalism (Moses, 2006: 19). National borders first emerged when nation-states began to materialize in Europe in the late 1700s (Amin-Khan, 2012: 22). Not coincidentally, the emergence of national borders occurred alongside the rise of industrial capitalism. National borders function as a protective barrier surrounding the capitalist economy of particular states. In the colonial era, race and ethnicity become intertwined in the spread of capitalism, the development of borders around capitalist states became increasingly pronounced in the post-colonial or the post-Second World War period. This has exacerbated in the era of globalization where international borders serve to insulate developed capitalist states from migration of displaced and impoverished individuals from the Global South who have been ravaged by policies of neoliberalism (Amin-Khan, 2012: 22). The liberalization of international borders for capital and commodities has created vast fortunes for those in the Global North while simultaneously under developing the local economies of the world's poorest inhabitants. The result has been a growing disparity between the rich and poor, both across countries and within them (Moses, 2006: 19).

Although the majority of the world's migration takes place strictly between countries within the Global North or the Global South, the most contentious migration patterns are the result of flows from less developed to more developed countries. Migration from the Global South to the Global North occurs in three main areas. Skilled workers who legally emigrate temporarily or permanently to rich countries, unskilled migrants that enter developed countries illegally looking for employment, and the involuntary movement of people, whether skilled or unskilled, across borders to seek asylum (Bhagwati, 2003). What the discourse surrounding the "crisis of migration" seeks to undermine is any critical understanding of the causes of global migration, its foundation in uneven development and the continued subjugation of the Global 
South through the policies of neoliberal globalization undertaken in the Global North (Munk, 2012:45).

The greater freedom of mobility granted to capital and commodities characterized by the neoliberal era have occurred alongside a restriction of the freedom of mobility for people. Yet increasing restrictions on migration have not led to a reduction in the number of people crossing international borders (Anderson, Sharma, and Wright, 2009:6). Rather, migrants are forced to take greater risks in order to move freely. Paradoxically, as the ability of states to control migration has shrunk, the desire to do so has increased. Despite efforts to create a "fortress North America", governments have been unable to stop people from crossing international borders. Half a million foreigners bypass American border defenses each year. Some enter covertly, while most overstay their visas and then work illicitly. Rather than preventing immigration, the increasingly draconian policies put in place by governments in the Global North, particularly in the wake of the growing security concerns following the September 11 terrorist attacks have been successful only in driving migration underground (LeGrain, 2009). There must be a shift in the way global migration is addressed. Governments must reorient their policies from attempting to curtail migration to working with it in order to implement a system that is beneficial for all (Bhagwati, 2003) Any attempt to reorient migration policies must begin by examining the underlying issues that cause migration in the first place.

Scholarship surrounding migration generally focuses on formulating recommendations for improving the immigration system, however, few scholars have focused their attention on questioning the foundational premises of this system. Laws and policies regarding immigration are premised on the fundamental idea that to a certain extent it is "permissible, desirable, and necessary to restrict immigration and to reduce the permeability of borders" (Johnson, 
2003:193). Those who advocate for open border migration policies challenge the position that the right to control people's mobility is a necessary and legitimate extension of state sovereignty. In order to argue against restrictive migration controls it is necessary to examine international borders as ideological, generating and reinforcing inequality (Anderson, Sharma, and Wright, 2009:5). Calls for open borders are made based on the recognition that borders between nations are unquestionably legal and social constructs that are given meaning only because there is meaning attached to them (Johnson, 2003:195). Anderson, Sharma and Wright (2009) argue that, "while international borders are presented as filters sorting people into categories of desirable/non-desirable, skilled/unskilled, genuine/bogus, worker, wife, refugee, and so on, the primary function of borders are to place people into new types of power relations relative to others" (p.6). Assigning rights based on citizenship or legal status allows for the exploitation of those who are not citizens and therefore cannot access their rights.

This paper will engage with the scholarship surrounding calls for open borders. Through a critical social research lens, it will examine the ways in which international borders maintain global inequality. It will question whether it is possible to theorize open borders in the face of a world system characterized by enormous global inequality and it will seek to determine what conditions must be met before a borderless world can be considered. This paper will begin with an explanation of the methodology and positionality from which this research has been created followed by a review of the literature on open borders. It will examine the factors that drive the migratory process including a discussion of neoclassical explanations of migration, as well as the social structures that impact migration and the impact of border controls on people's ability to migrate. It will then examine the link between migratory processes and underdevelopment including the role of neoliberalism and capitalist restructuring in the Global South and the impact 
of remittances in the developing world. Finally, this paper will return to the question of open borders. It will argue that discussions of a borderless world can only take place in the context of a discussion about how to remove such factors as global inequality, which prompts migration in the first place. In line with the recognition that mobility is a central feature of contemporary societies, this paper will offer a discussion of how migration flows are to be governed in accordance with the principles and values of liberal democratic states (Zapata-Barrero and Pécoud, 2012: 1160). It is necessary for studies of migration to be embedded within the broader debates around the political economy of globalization and its implications for development (Munck, 2008:1228). 


\section{CHAPTER 2: METHODOLOGY}

This paper will examine the topic of open borders by using two main methods: a review

of the existing relevant literature on open borders and a critical analysis of migration theories and the impact of the rise of neoliberalism. Literature review was selected as the primary method of research due to the conceptual nature of this MRP. While this paper will begin with an exploration of the theoretical and conceptual literature on open borders, this will be juxtaposed with theories of migration and neoliberalism offering an original understanding of the impediments and obstacles to achieving a state of open borders.

\section{Critical Social Research}

Critical social research is used to describe any research that challenges conventional knowledge bases and methodologies, both quantitative and qualitative, that makes claims of scientific objectivity. Critical social research views the world as being characterized by extreme inequalities and injustices. The result of this is that our knowledge of ourselves, and our world is caught up in those practices and structures of inequality and domination (Carroll, 2004: 2). Critical social research attempts to reveal the socio-historical specificity of knowledge and to shed light on how particular knowledge reproduces structural relations of inequality and oppression. In this way, it is accepted that research has often been a tool of domination that has helped to perpetuate and maintain power relations of inequality (Kirby and McKenna, 2004: 68). Critical social research recognizes that there is a need for social research to move beyond the traditional academic understanding that knowledge can be created objectively. Rather, it must be recognized that the creation of knowledge is always informed by an individual's lived experience and therefore must begin to incorporate the personal and political context from which knowledge 
has been created (Kirby and McKenna, 2004: 69). Critical social research acknowledges people who pursue social research do so from a position of power and that this has implications that need to be acknowledged (Kirby and McKenna, 2004: 69).

Although some scholars argue that research is capable of representing all groups equally if created in an objective manner, critical social research refutes these positivist claims (Kirby and McKenna, 2004: 68). By accepting that research and knowledge are produced in a manner that represents the political and social interests of particular groups, this paper will demonstrate that the majority of studies of migration and global development have been done through a Western dominant lens. Major institutions, such as the media, educational institutions, and government agencies interpret and choose facts in such a way as to enable them to construct an image of the world that is beneficial to their needs. In this case, the creation of a "crisis of migration" perception whereby any liberalization of open borders would result in millions of people from the Global South migrating to take "native" jobs.

Knowledge is never free of socio-political context and that context is organized around relations of power, meaning that knowledge is unavoidably implicated in those relations (Carroll, 2004: 2). Migration policies are created within international processes deeply rooted in colonial history. Currently, migration policies overlook these colonial roots and instead focus on perceived threats to state sovereignty exacerbated by the September 11 terrorist attacks (Bauder, 2003:168). The goal of employing this method has been to create a piece of research that begins to reflect this history of colonialism and highlight the ways in which colonialism and neoliberal ideologies have impacted the popular understanding of the forces that drive migration and global inequality. 


\section{Political Economy Approach}

This paper will examine the theoretical project of open borders from a political economy perspective. Studies of the global political economy are concerned primarily with the ways in which political forces, including states and institutions, shape the systems through which economic interactions are expressed and alternatively, the way that economic interests including various markets, are able to shape political structures. The implications of a political economy approach are that studies of migration must incorporate and analysis of political and economic influences on international migration. The goal of employing this perspective has been to emphasize the centrality of the neoliberal capitalist state to existing migration policies in the Global North. In combination with a critical social research lens, an analysis of the political economy of migration will critically examine the underlying forces that lead to migration and provide an avenue through which to theorize an alternative system of migration incorporating broad political and economic change. 


\section{CHAPTER 3: LITERATURE REVIEW}

\section{Open Borders}

Any discussion of open borders must begin with an explanation of what international borders are. Kukathas (2011) describes borders as "geographic boundaries demarcating or defining political entities or legal jurisdictions” (p.325). Borders consist not only of physical barriers but also exist as intangible obstacles to the integration and settlement of newcomers within a new society. Borders function not only as barriers to separate land but also across water, through streets, and within buildings. Anderson, Sharma, and Wright (2009) attest to the abstract nature of borders as they describe how "borders follow people and surround them as they try to access paid labour, welfare benefits, health, labour protections, education, civil associations, and justice.” (p.6). In this way, borders exist any time that a migrant attempts to access resources, services, and rights within their host country. Physical barriers, when they exist at all, tend to come in the form of controls exercised at checkpoints where borders are crossed. Often, these controls involve the presentation of identity papers such as passports, visas, or other entry permits before an individual is allowed to enter a given territory (Kukathas, 2011:325).

In discussing borders it is necessary to recognize that they are ideological. Borders are not fixed. Rather, they are formed and reformed in response to political and economic transformations. Most national borders were established less than two centuries ago. In Africa, borders were imposed as part of colonial domination, reflecting common trade routes rather than demarcating populations with shared traditions, language and history (Fernandez-Kelly and Massey, 2007: 98). Yet as easily as borders can be drawn, as with the division of colonial Africa, they can also be torn down. International agreements including the North American Free Trade 
Agreement (NAFTA) eliminated barriers to capital mobility. Another example of the elimination of international borders can be seen in the European Union (EU) which abolished border controls between it's member countries allowing people to travel, trade and work throughout most of the continent. Whether tangible or not, the creation and removal of borders always exposes hierarchies of power and authority (Fernandez-Kelly and Massey, 2007: 98).

It is also necessary to clarify the difference between arguments in favor of "open borders" and arguments in favor of "no borders". Most advocates of open borders accept the sovereignty of territorial nation states in so far as they function as clear physical demarcations between the territories of nation-states, but support the presumption of free movement across these borders. Advocates of "no borders" do not recognize the legitimacy of nation-states. They may accept open borders as a partial step towards the achievement of "no borders" but the total elimination of borders is the ultimate goal. According to Anderson, Sharma, and Wright (2009), "What distinguishes a No Borders politics from other immigrant-rights approaches is their refusal to settle for "fairer" immigration laws. Within a No Borders politics, it is understood that the border-control practices of national states not only reflect people's unequal rights but also produce this inequality." (p.11). A radical No Borders politics acknowledges that it is part of revolutionary change. If successful, the complete elimination of borders would require a global reshaping of economies and societies in a way that is not compatible with capitalism, nationalism, or the mode of state-controlled belonging that is citizenship (Anderson, Sharma, and Wright, 2009: 12). This paper will deal primarily with arguments for open borders, understood as calling for the removal of immigration controls and the free movement of people between nation-states. 


\section{Arguments for Open Borders}

A major theme within the literature surrounding open border policies is the notion that open borders are a necessary part of the creation of a global system of common rights (Anderson, Sharma, and Wright, 2009:12, Hayter, 2004: 7). Scholars argue that access to open borders would serve as an effective vehicle for wealth redistribution. According to Lenard (2010), "if a general practice of freedom of movement were adopted, or simply if rich countries embraced an “open admissions" policy - this could serve as a partial equivalent to the transfer of resources" (p.644). Freedom of movement is therefore an important means to achieve widely espoused goals including greater economic justice and a fairer distribution of resources (Dowty, 1987:19). It is widely understood that immigration controls impose harsh suffering on migrants and refugees in order to deter "non-desirable" migrants (Anderson, 2010: 308, Hayter, 2001:152). Border controls undermine a long list of human rights including the right not to be subjected to inhuman and degrading treatment, the right not to be tortured, the right not to be arbitrarily arrested and detained, the right to a fair trial by a properly constituted court, the right to a family life, and the right to seek and find work wherever available (Hayter, 2001:152). There is an understanding within the literature that international borders not only maintain the global inequality characterized by the current world system, but they also create it through the allocation of precarious legal statuses within a territory.

Although most scholars recognize that open border policies are the key to a more equitable global regime, a major issue identified within the literature is the realization that within the current world system, open borders would privilege only the small number of migrants who would prefer, and have the means, to move across them (Lenard, 2010:650). Mass immigration would not likely exist in an ideal world. If all states were reasonably prosperous and reasonably 
liberal the primary forces currently prompting immigration would be insignificant (Seglow, 2005:117). Many factors impelling people to migrate are themselves manifestations of deep injustices in one's home country caused by the global system. Eliminating border controls would not necessarily benefit the world's poorest inhabitants since many structures of inequality, such as gender, race, and class, are not affected by transnational mobility (Higgins, 2008:530). In fact, studies have demonstrated that these factors impede the settlement of newcomers in their host society. In response to this, Carens argues that open borders would do little to address the deeprooted global injustices and would therefore not affect the greater population who do not have the means to migrate (1999:1089).

Profound social injustices, rooted in structures of neoliberal globalization are what make the right to move freely such an urgent and important freedom. Therefore, it remains true that the primary barriers to a fairer distribution of the world's wealth are not necessarily immigration restrictions, but a global economic system that favours richer states (Seglow, 2005:121). Many scholars suggest that open borders are an ideal worth striving for, but must be considered only with relation to other political and economic reforms. Those reforms would work to achieve further economic development among the Global South (Seglow, 2005:122).

The corportization, commodification and privatization of public assets with a goal toward capital accumulation are a central feature of the neoliberal project (Harvey, 2006: 44). Public goods including utilities (water, transportation, and telecommunications) and social welfare provisions (social housing, education, health care, and pensions) have all been privatized to a certain extent throughout the capitalist world amounting to the transfer of assets from the public realm to the private and class-privileged domain (Harvey, 2006: 44). Neoliberal states seek the reduction of barriers to the movement of capital across borders and the opening of markets for 
both commodities and monetary capital to global forces of capital accumulation (Harvey, 2006: 26). These barriers are not reduced for human beings. Rather, they are raised, making it increasingly difficult for people to cross international borders. This emerges from neoliberalism, which views rights as an extension of the territorial state. Despite conversations surrounding "universal" human rights, the reality is that rights require the protection of the state apparatus to ensure that they are enforced. This means that rights are fundamentally conditional upon citizenship (Harvey, 2006: 55). The existence of borders and the very notion of state sovereignty intrinsic to neoliberalism must be questioned (Zapata-Barrero and Pécoud, 2012: 1160).

Another issue identified in the literature on open borders is the idea that the migration of highly skilled people mainly benefits the migrants themselves, rather than the economy of the sending country (Seglow, 2005:121). Only those who had the economic means to migrate would be capable emigrating. This could result in what is commonly referred to as "brain drain". It is recognized that open borders may mean the loss of engineers, doctors, and other highly skilled professionals to more prosperous areas of the world where they would be able to receive higher wages for their trade than would be possible in their country of origin, resulting in diminished control over economic planning in sending countries (Dowty, 1987:17). However, this phenomenon is also experienced through current migration policies in the Global North that allow skilled workers to immigrate while keeping the low skilled workers out. An important challenge to open borders is the idea that it could only work in a world marked by relative equality. The liberalization of borders would not immediately Many scholars argue that while the liberalization of borders is not a flawless solution, calls for open borders should not be abandoned due to their radical nature (Carens, 1987: 266, Johnson, 2003:204, Dowty, 1987:19). 
Migration is sometimes considered a second-best option for addressing distributional concerns. To the extent that motivations for migration are economic, some theorists argue it is more beneficial to bring resources to people, rather than creating a system that allows people to migrate towards resources (Bartram, 2010:344). In reference to a study of Caribbean rates of emigration by Bob Sutcliffe, Hayter, (2004) estimates that the total removal of restrictions on immigration would lead to an additional 24 million migrants per year. The result would be a growth of only 2.4 per cent per year in the population of the industrialized countries (p.153). The study found that the majority of the Caribbean emigration took place in years when unemployment was high in the Caribbean and much lower the destination countries. Migration from the small islands of the Caribbean was facilitated by the existence of communities in the recipient countries and common languages and education systems. In areas that do not share these characteristics, Hayter proposes that there has been virtually no emigration (Hayter, 2004:154).

This study points to the fact that on the whole most people do not want to uproot themselves, abandon their families, and suffer the hardships and risks associated with migration (Hayter, 2004:154). For this reason, it is necessary to examine why people choose not to migrate. The literature on migration deals almost exclusively with neoclassical explanations of migration. Neoclassical explanations of migration point to particular "push" and "pull" factors associated with the rational choice to move to a destination where an individual will be provided with better living conditions (Bush, 2007: 53, Arango, 2000: 285). Despite its dominance in migration theory, neoclassical explanations of migration are over simplified and neglect many of the microlevel factors involved in the decision to migrate. More attention should be paid to family 
networks, kinship systems, social systems and social structures in general that cause people to stay, rather than focusing solely on those pressures that cause people to leave.

While various authors (Seglow, 2005, Carens, 1999, Higgins, 2008, and Lenard, 2010) identify the need to examine open borders within the context of broader political and economic reforms, very little has been written on what these reforms would consist of. This paper will seek to fill the gap in the literature, which does not make the connection between arguments for open borders and the structural factors inherent in the global system that lead to migration. In order to assess the possibility of open borders it is necessary to examine those factors that drive the migratory process. These include factors arising from the social dynamics of the migratory process, factors linked to globalization, transnationalism, North-South relationships, and factors within political systems (Castles, 2004: 857). 


\section{CHAPTER 4: FACTORS THAT DRIVE THE MIGRATORY PROCESS}

A review of the literature on open borders has revealed a need to explore the impact that policies and societal attitudes have on migratory flows and development. An understanding of the factors that prompt migration will allow for greater insight into the merits of open border policies. This section of the paper will examine various theories of migration in order to gain a holistic view of the factors that drive migration. It will explore neoclassical explanations of migration and argue that the reasons for migration are oversimplified in this classical explanation of "push" and "pull” factors with it's central focus on migration as a result of a rationally calculated cost/benefit analysis. This section will focus on neoclassical explanations of migration because this is the dominant lens through which migration has been viewed, and therefore this is the understanding of migration that many scholars take when theorizing open borders. As an alternative to neoclassical theories, this section will put forth theories of migration including those that take into consideration various social structures such as Network Theory.

Dramatic progress in communication, a drastic reduction in transportation costs and the expansion of social media and networking tools are all factors that make national migration an intricate social process (Ghosh, 2000: 9). This has led to the emergence of alternative theories that focus on the impact of social structures including family and kinship ties as well as their impact on the state and the political context in which migration takes place. This section will also examine the impact that admission restrictions have on either deterring or encouraging migration processes. This will include a discussion of the increasing securitization and the xenophobic reactions to migration that are characteristics of many countries in the global North, and the impact that this has on migration flows. 


\section{$\underline{\text { Neoclassical Explanations of Migration }}$}

The dominant approach to understanding the persistence of global migration has been to explore the motivations of people who migrate. These motivations are usually understood by neoclassical migration theorists in relation to particular "push" and "pull" factors that are understood as prompting migration. Factors that are considered to "push" people to migrate include poverty, war, household conflict, inadequate living wages, and other conflict. The "pull" factors are those that draw people to potential host countries. They include economic growth and the belief that the host country will provide better living conditions and the opportunity for a better future (Bush, 2007: 53). The primary explanation for migration promoted by neoclassical economics has been the "push-pull" theory in its various manifestations. Neoclassical explanations of migration are based on tenets such as rational choice, utility maximization, expected net returns, factor mobility, and wage differentials (Arango, 2000: 285). This view of migration is characterized by a movement of primarily migrant workers that are propelled by the dynamics of the transnational capitalist economy. According to neoclassical explanations of migration it is the global capitalist economy that simultaneously determines both the "push" and the “pull” factors (Zolberg, 1989: 407).

Arango (2000) explains that for neoclassical economists,

"Migration is understood as the result of individual decisions made by rational actors who seek to improve their well-being by moving to places where the reward for their labour will be higher than what they would receive in their home country, in a measure sufficient to offset the tangible and intangible costs involved in the move." (p.285). 
Migration is therefore understood to be a voluntary act which rests on the comparison between the present situation of the individual and the expected net gain of moving. The decision to migrate therefore and results from a calculation of utility maximization.

According neoclassical theory, migrants will tend to move to a destination where a higher net return is expected (Arango, 2000: 285). International migration is therefore understood as being caused by geographical differences in the supply of and demand for labor. Countries with a large surplus of labour relative to capital have a low equilibrium market wage, while countries with a limited supply of labour relative to capital are characterized by a high market wage. The resulting differential in wages causes workers to move from low wage countries to high wage countries in hopes of finding a better job (Massey et. al, 1993: 433). Typically countries of the Global South are characterized by a large abundance of labour relative to capital whereas those countries in the global North tend to have a limited supply of labour relative to capital. It is this economic mismatch that is understood by neoclassical theorists to be the driving force behind global migration.

The simple and compelling explanation of international migration offered by neoclassical macroeconomics has strongly shaped public thinking and has provided the intellectual basis for much current immigration policy (Massey et. al, 1993: 433). However the language of "push" and "pull" factors and of forced and voluntary migration oversimplifies this complicated process. Neoclassical explanations of migration contain several implicit propositions and assumptions about migration that have shaped both migration policies and the literature on open borders. Neoclassical understandings of migration ultimately propose that the international migration of workers is caused by differences in wage rates between countries and that therefore eliminating wage differentials will result in less international migration of labor (Massey et. al, 1993: 434). 
While economic disparities are important, they are by no means sufficient for migration flows to take place (Arango, 2000: 287). Migration involves considerable costs and risks as well as knowledge and social networks. Neoclassical theories of migration propose that labour markets are the primary mechanisms by which international flows of labour are compelled. This means that neoclassical theories do not consider that other types of markets may have important effects on international migration. Neoclassical theories of migration downplay non-economic factors, which are bound to play an important role in such an existential decision as migration (Arango, 2000: 287).

Finally, neoclassical economics posits that the way for governments to control migration flows is to regulate or influence labour markets in sending and receiving countries (Massey et. al., 1993: 434). Although migration emanates from the desire to improve one's livelihood, it is rarely the poorest people who migrate. Rather than absolute poverty, a certain level of socioeconomic development combined with relative deprivation in the form of global inequality of development opportunities is necessary for migration to take place (De Haas, 2005: 1271). Contrary to what one might expect based on neoclassical theories of migration, it is important to note that rising incomes in the global South increase the likelihood of migration for work rather than decrease it (Bush, 2007: 55). The leading emigration countries (such as Mexico, Morocco, Turkey, and the Philippines) are not among the least developed countries. Several studies suggest that economic growth related to trade liberalization (NAFTA, and the EU's association agreements with North Africa and the Middle East) leads to more rather than less migration in the short to medium run (De Haas, 2004: 1271)

The model of neoclassical economics cannot explain why so many people choose to stay behind, given the opportunity for higher wages or better welfare systems given the vast 
disparities in income, wages and levels of welfare that exist among countries. Nor does it explain why there is disproportionately more migration from certain countries than from others (Munk, 2008:1230). What the language of "push" and "pull" is successful in doing is disguising the centrality of capitalism to migration (Bush, 2007: 54). To a large extent all migration is forced because the imperatives driving mobility reduce the possibility for choice. In order to explore the factors that drive the migratory process it is necessary to form a more comprehensive view of the factors prompting migration, factors that stretch beyond solely economic explanations.

The idea that labour markets dictate migration trends has largely guided labour market segmentation theory, which is often used in order to explain global migration patterns. Labor market segmentation theory is premised on the idea that international labour migration is largely demand-based and is initiated by recruitment on the part of employers in developed societies, or by governments acting on their behalf. Since the demand for immigrant workers grows out of the structural needs of the economy and is expressed through recruitment practices rather than wage offers, international wage differentials are neither a necessary nor a sufficient condition for labour migration to occur. In this way labor market segmentation theory challenges neoclassical economic theories on the grounds that workers and jobs are not equally matched by a universal market mechanism. Instead, this theory suggests that jobs and labour are divided between market segments (Bauder, 2001: 38). This means that low-level wages in immigrant receiving societies do not rise in response to a decrease in the supply of immigrant workers; they are held down by social and institutional mechanisms and are not free to respond to shifts in supply and demand. Governments are unlikely to influence international migration through policies that produce small changes in wages or employment rates; immigrants fill a structural demand for labour that is built into modern, post-industrial economies, and influencing this demand requires major 
changes in economic organization (Massey et. al, 1993: 444). While labour market segmentation theory provides an alternative to neoclassical understandings of migration it still fails to consider the role that non-economic factors play in the decision to migrate.

\section{$\underline{\text { Social Structures }}$}

Castles (2004) explains that, "migrants are not isolated individuals who react to market stimuli and bureaucratic rules, but social beings who seek to achieve better outcomes for themselves, their families, and their communities by actively shaping the migratory processes." (p.860). In some of the most important contemporary migration regions labour migration is severely curtailed (although there are a number of exceptions to this) the largest migration flows tend to result from legal entitlement, such as family reunification and the granting of asylum (Arango, 2000: 293). Migration is a complex, multidimensional phenomenon that encompasses economic, social, cultural and political dimensions that cannot be entirely captured entirely by an economic explanation (Marchand, 2008: 1378). Neoclassical economic theories such as dual labour market theory generally ignore the micro-level decision processes, such as those decisions made by families, households, or other culturally defined units of production and consumption. Taking into consideration culturally defined forces, new theories of migration consider conditions in a variety of markets, not just labour markets. Alternative theories of migration take into consideration the role that various social structures play in a household decision to uproot themselves and move to a new territory.

An alternative view of migration, which takes into account these social structures, is network theory. Network theory argues that migration networks are sets of interpersonal ties that connect migrants, former migrants and non-migrants in origin and destination areas through ties 
of kinship, friendship and shared community origin. This theory is based on the idea that people around the world construct elaborate systems of social support, known as "networks" in order to meet a variety of human needs (Krissman, 2005: 6). These ties increase the likelihood of international movement because the formation of migration networks lower the costs and risks associated with movement and increase the expected returns to migration (Massey et. al, 1993:448). While kinship ties may be required to access many networks, relationship webs also connect unrelated individuals based on a sense of shared origin (Krissman, 2005: 6).

It is argued that once begun, international migration tends to expand over time until network connections have diffused so widely in a sending region that all people who wish to migrate can do so without difficulty. Then migration begins to decelerate. As international migration becomes institutionalized through formation and elaboration of networks it becomes progressively independent of the factors that originally caused it, whether they are structural or individual. As networks expand and the costs and risks of migration fall, the flow becomes less selective in socioeconomic terms and more representative of the sending community or society (Massey et. al, 1993: 450). Certain immigration policies, such as those intended to promote reunification between immigrants and their families abroad, work at cross purposes with control of immigration flows, since they reinforce migrant networks by giving members of kinship networks special rights of entry (Massey et. al, 1993: 450).

Theories that focus on the impact of social structures on immigration have a different set of propositions and hypotheses from that of neoclassical theory, and they lead to a very different set of policy prescriptions. Theories that focus on social structures find that families, households or other culturally defined units of production and consumption are the appropriate units of analysis for migration research, rather than the autonomous individual as put forth by 
neoclassical theories of migration. Theories of social structures also suggest that differences in wages are not the sole condition under which international migration occurs. Rather, households may have strong incentives to undertake transnational movement even in the absence of wage differentials (Massey et. al., 1993: 439). International migration and local employment or local production are not mutually exclusive possibilities. There are strong incentives for households to engage in both migration and local activities. An increase in the returns to local economic activities may heighten the attractiveness of migration as a means of overcoming capital and risk constraints on investing in those activities. Thus economic development within sending regions need not reduce the pressures for international migration (Massey et. al., 1993:439). Taking into consideration the propositions put forward by Network Theory and other theories that emphasize the role of social structures means that governments are able to influence the rates of migration not only through policies that influence labor markets, but also through policies that shape insurance markets, capital markets, and futures markets. The existence of a strong social safety net, including employment insurance, health care, or government assisted housing, within a particular host society significantly affects the incentives for international migration (Massey et. al, 1993: 439).

\section{Racialization, Xenophobia, and Cultural Distinction}

In examining the reasons why people migrate it is necessary to take into consideration the role that border controls play in either drawing or deterring immigration to a host country. For most receiving states, no other source of tension and anxiety has been more powerful than the fear, both real and perceived, mass migration from the Global South (Ghosh, 2000: 10). Security has increasingly become the dominant lens through which migration is viewed in the West (Munck, 2008: 1232). The "crisis of migration" discourse positions international migrants as 
posing a threat to the cultural security of receiving countries as "native" citizens fear being culturally and politically dominated by immigrants who are perceived to have different customs and value systems (Lowry, 2002: 31). The natural flow of migrants across geographic, political, and cultural space can be seen both as a natural consequence of globalization as well as a perceived threat to order, security and identity in the Global North (Munk, 2008: 1233). Since the terrorist attacks of September 11, 2001 there has been a tightening of border controls throughout the Global North. Yet it is necessary to note that none of the perpetrators involved in the September 11, 2001 terrorist attacks were immigrants or asylum seekers. Rather, they had entered legally on visas. Despite the vastly increased surveillance since September 11, only a handful of immigrants have ever been suspected of involvement in terrorist activities (Zolberg, 2012: 1211).

Increasingly, nation states are enacting ever more exclusionary measures to stop migrants from accessing sovereign territory by preventing an individual's ability to legally gain employment or seek political asylum (Ashutosh, 2011:21). The powerful impact of admission restrictions on processes, determinants, and selectivity of migration should be incorporated into any discussion of the reasons people migrate (Arango, 2000: 293). In Canada, strategies for tightening border controls include implementing repressive and restrictive refugee and immigration policies. For example, the "Smart Border" initiative, between Canada and the United States, provides a number of protocols for increased cooperation between state authorities, including information exchange and the harmonization of immigration policies. New and proliferating modes of surveillance have led to new practices and technologies of citizenship, such as new categories of identity and the proposed introduction of "bio-metric" identification cards. In this increasingly securitized climate, the concept of "Fortress North America" has 
accurately conveyed the restrictive nature of new security policies. Despite the increasingly restrictive entrance requirements for migrants, the modern era has simultaneously been characterized by a relaxation of restrictions for capital, goods, and commodities.

The xenophobic reaction to migration is in many ways a reaction to the insecurities created by globalization, with its increased social and geographical levels of inequality (Munk, 2008: 1233). There is most visibly increasing anti-immigrant sentiment in the industrial receiving countries of Western Europe (Ghosh, 2000: 14). The xenophobic reaction to migrants can be seen both from above, in the form of anti-immigrant legislation at the federal and state level, and below, through racist anti-immigrant groups forming within civil society (Wright, 2008: 188). The politicization of migration is arguably a way of coping with the paradox existing between the imperatives of neoliberal globalization, notably, the free movement of capital, goods, and labour, alongside the continued commitment to national security in light of perceived terrorist threats. While neoliberals still find it important not to inhibit capital, service, and labour mobility in the interest of capital growth, it is understood that this will be accompanied by an increase in "undesirable" migration. However, there is a huge gap between desiring labor mobility in the interest of local economies and the neoliberal driven attitude that results in the adoption of policies that restrict the mobility of labour.

Migration is thus clearly not a purely economic process dictated by market forces but is also a key element in shaping the contemporary culture of politics. The recent initiatives to tighten the Canadian border suggest, "that Canadians have something to fear from newcomers" (Lowry, 2002: 31). The social construction of migration as endangering state sovereignty and national security has a profound impact on the whole discourse around migration, which is always over-determined by the securitization drive (Munk, 2008: 1231). Concerns about the 
increasing "flood" of migrants from the Global South are informed by the urge to protect national culture (Lowry, 2002: 31). Countries in the Global North must undertake a dramatic shift in the way they respond to the influx of economic migrants and asylum seekers.

Inducements or punishments based on migrants' countries of origin are not successful in curbing migration flows, nor are increasingly draconian border-control measures, sanctions on employers, or harsher penalties for the irregular migrants themselves (Bhagwati, 2003: 102). The majority of these restrictive policy measures have been devoid of support from complementary and proactive measures to address the root causes that generate migration in sending countries (Ghosh, 2000: 14).

It is necessary, therefore, to consider all the actors, structures and pressures involved in developing migration networks in order to ascertain the principle causes of international migration and to recommend policies to regulate these flows (Krissman, 2005: 5). A discussion of the politics of open borders must begin with an informed understanding of the reasons why people migrate or stay. Many arguments for open borders have been informed by neoclassical understandings of migration that oversimplify the migratory process. An accurate understanding of why people migrate will not only lead to important conclusions about why liberalization of international borders is important, but also what steps need to be taken in order for this to occur. 


\section{CHAPTER 5: THE LINK BETWEEN MIGRATORY PROCESSES AND DEPENDENCY}

After taking into consideration the various factors that influence global migration flows, including labour, social networks, family structures, and border controls, this section will examine whether and in what way global migration contributes to poverty reduction and other development outcomes. Arguments for open borders are often premised on the idea that facilitating free migration would benefit sending countries in terms of development. The goal of this section is to interrogate the relationship between migration and development in order to determine the effect that liberalization of borders would have on countries of the Global South. The global phenomenon of labour migration has given rise to contradictory policy perspectives about the desirability of migration flows and their consequences for economic development (Keely and Tran, 1989: 500). Many scholars have suggested a linkage between the migratory process and dependency. Portes (1978) demonstrated that the effect of dependent development has been various structural distortions that exacerbated the "push" conditions and triggered the onset of migrations from developing to developed countries. The North-South divide continues to be an overarching feature of the modern global system and is the inescapable context within which international migration must be studied. The uneven development of global capitalism sets the parameters of both migration processes and development prospects in the Global South (Munk, 2008: 1228).

Recent scholarship is inclined to see voluntary international migration as a stage of development, indicating a transition from a very low level of development to a lower-middle income level. According to this view, migration stems not from underdevelopment but from development itself (Baldwin-Edwards, 2008: 1454). While development tends initially to stimulate migration because social and economic development tends to raise people's aspirations 
and enhance the resources necessary to move, it is necessary to recognize that migration does not automatically lead to more development. Migration and remittances may potentially contribute to development, but the specific political, economic and social circumstances in both the sending and receiving countries determine the extent to which this potential is recognized (NybergSorensen, Van Hear, and Engberg-Pederson, 2002: 51, De Haas, 2005: 1275). Poverty underlies much of current migration but it is not the direct cause of it. The poorest of the poor lack the resources and network connections necessary for mobility (Nyberg-Sorensen, Van Hear, and Engberg-Pederson, 2002: 51).

In order to understand the circumstances under which migration and development are most positively correlated it is necessary to isolate key migration questions from the many other issues that lead to global inequality. This section will address the uneven development of global capitalism in order to understand the effect that neoliberal policies and capitalist restructuring had on the underdevelopment and creation of a precarious work force in the global South. It will also address the outcomes of the migration-development nexus such as remittances and "brain drain". It is apparent that there is a link between migration and development, this section will seek to determine under what circumstances migration and development are most positively correlated.

\section{Neoliberalism and Capitalist Restructuring}

While migration is unquestionably a global issue it has primarily been studied from the perspective of receiving countries, with little or no understanding of the political economy of development, which has caused migratory flows in the first place (Munk, 2008:1228). In discussing the relationship between migration and development it is necessary to study the 
principles that underpin neoliberal globalization. There is a need to change the ways in which neoliberal policies are applied in migrant-sending countries (Delgado-Wise, 2009: 768). In order to develop a greater understanding of contemporary neoliberal capitalism, it is first necessary to understand capital restructuring and its reliance on migrant labour in order to expand profitability (Ness, 2007: 431). According to multilateral agencies, such as the World Bank and International Monetary Fund (IMF), created by finance capitalists through trade agreements among states, the flow of migrant labor from South to North is vital to generating greater interdependence and cooperation between rich and poor countries (Ness, 2007: 437). In the neoliberal era, all multilateral agencies serve the interests of the ruling classes through financing private enterprise as opposed to public agencies (Ness, 2007: 438). Capital creates mass population movement to foment labor market crises that activate the migration of displaced workers and peasants who have no recourse but to uproot and move to urban cores in their home countries and abroad (Ness, 2007: 439).

Structural Adjustment:

Industrialized countries have done little in order to address the underdevelopment of the global South. Those efforts that have been undertaken have often done more harm than good. While global inequality traces its roots to colonialism, the prominent role of neoliberalism and its institutions including the International Monetary Fund (IMF) as well as the acceptance of the Washington Consensus mark an important change in the contemporary global system. In the event of a conflict between the integrity of the financial system and the well-being of a population, as was the case during the debt crisis of the 1980s, the neoliberal state will inevitably choose the former (Harvey, 2006: 27). Neoliberal economic policies were applied throughout the 
global South as a response to the financial problems precipitated by the debt crisis of the $1980 \mathrm{~s}$ (Fernandez-Kelly and Massey, 2007: 99).

Beginning in the 1970s, the rise in oil prices had a dramatic effect on the international credit market. Large amounts of money became available for lending purposes. Oil producers, primarily members of the OPEC had invested some of their money in Eurodollar markets. In an effort to make profitable investments, Western banks began providing what they perceived to be secure loans to governments in the global South. At the same time, developing countries were desperate for finances to help them industrialize their economies under the Import Substitution Industrialization model. States borrowed money to invest in industrialization with a plan to pay off the loans from the profits of their new industries (O'Brien and Williams, 2007: 223). Loans were seen as an attractive model because they did not come with the influence of foreign transnational corporations that accompanied Foreign Direct Investment and few states had funds of their own to invest (O’Brien and Williams, 2007: 223). While much of the money was invested into industrialization projects large amounts also were also lost to frivolous spending by heads of state.

The debt crisis erupted in 1982 due to a number of oil shocks, which resulted in skyrocketing interest rates. Whereas the interest rates on international loans were about 2 per cent in the early 1970s, they rose to over 18 per cent in the early 1980s (O'Brien and Williams, 2007: 223). Many countries, particularly in Latin America and Sub-Saharan Africa were no longer able to service their debts, let alone hope to repay their debt entirely. It is under these conditions that the IMF emerged as a prominent global force. The Fund negotiated standby loans with indebted countries offering temporary assistance to indebted states. The loans provided by the IMF were conditional on the implementation of Structural Adjustment Programs (SAPs). The 
Washington Consensus stipulated that the best path to economic development was through financial and trade liberalization and that international institutions should persuade countries to adopt such measures as quickly as possible (O’Brien and Wiliams, 2007: 224). Thus, SAPs were a product of this consensus. They consisted of medium term, generally three to five year programs, intended to alter and reform the economic structures of highly indebted countries as a condition for receiving international loans. These programs involved the necessity for privatization, liberalization of economies to trade and foreign investment as well as fiscal restraint in the form of reduced state subsidies and bureaucracies in order to balance national budgets. The result of these programs has been catastrophic for developing nations. Many countries of the global South were poorer in 1990 than they were in 1980 leading to the wellknown title of the 1980s as the "lost decade" of development.

\section{The Creation of a Precarious Work Force}

The 1970s and 1980s also resulted in a radical reconfiguration of economies in the Global North. The debt crisis resulted in waves of plant closings and millions of manufacturing jobs exported to developing countries or eliminated in favor of cheaper production elsewhere (Fernandez-Kelly and Massey, 2007: 100). This was the beginning of the modern day reliance on the Global South for cheap labour. In many countries of the Global South a clear set of specific programmes including increased labour force participation and other active labour market measures, appropriate structural and technological adjustment have been woven into a robust and balanced policy package to satisfy unmet labour demand and establish a dynamic labour market equilibrium (Ghosh, 2000:14). Far from contributing to the development of migrant-sending countries, structural adjustment programs have reinforced the dynamics of underdevelopment and transformed many countries into "people-exporting" countries (Delgado-Wise, 2009: 768). 
Underdeveloped countries find themselves with massive population reserves, and therefore a large volume of surplus population, well beyond the conventional formulation of unemployed citizens, members that are unable to find decent working conditions in their countries of origin for ensuring personal and family reproduction (Delgado-Wise, 2009: 769). In this way, labour migration can become much like the export of commodities. Importers control the market price, in the case of labour supply because it is so bountiful in developing countries. Sending countries therefore fall into a dependent position at the mercy of a market they do not control and which they can only minimally influence (Keely and Tran, 1989: 501).

The "formalization thesis" developed by Williams and Windebank assumes that economic development leads to a shift away from informal employment and toward formal employment. However, in recent times the opposite trend has taken place. Industrialized societies have become increasingly reliant on the informal sector (Baldwin Edwards, 2008: 1455). The informal sector in advanced economies has emerged as a mechanism for achieving increased competitiveness in the context of relatively fixed high wage costs (Baldwin Edwards, 2008: 1454). The causes of illegal migration are ultimately found in the use and control of labor in different areas of the international economy (Portes, 1978: 472). Over the past two decades, illegal immigrants have taken up positions predominantly in the informal and secondary sectors, regardless of their skill levels or work experiences (Baldwin Edwards, 2008: 1455). Migrants contribute to an overall cheapening of the workforce since they tend to be employed in workintensive areas of production where they rescue or substitute for a national workforce that tends to earn higher wages and benefits (Delgado-Wise, 2009: 770).

Migration is both the cause and effect of a broader development process (Munck, 2008: 1237). Political and economic inequalities continue to exist and grow in a world that is arguably 
shrinking due to the forces of globalization (Moses, 2006: 30). The domination that was once accomplished through colonialism and imperialism is now accomplished through free trade agreements and "export-led development". Communities in the Global South are impoverished because of the ways in which their local economies have been incorporated into the world economy. Thus, underdevelopment is not about being left out of the global capitalist market, but about "being actively excluded from an unjust and unequal system of wealth creation" (Bush, 2007: xiv). Examples of this can be seen throughout Africa and much of South Asia. In an effort to escape poverty, repression and internal conflict, millions of people each year choose to emigrate (Moses, 2006: 30). Both the IMF and the World Bank need to reconsider their strategies for pursuing meaningful development in the Global South. Emphasis shold be placed on economic development, school funding, preventative health care, adequate housing, and new infrastructure in the Global South (Munk, 2008: 1237). Vast global economic inequality is an obvious reason to consider a world with free migration.

\section{$\underline{\text { Remittances }}$}

An argument often put forward in favour of a positive relationship between migration and development is the impact of remittances on the sending country. Migrants are able to influence the development of their home countries through the resources and assets that they send back or bring with them when they return home. These are known as remittances. Proponents of open border policies (Seglow, 2005, Portes, 1978, Dowty, 1987) point to the fact that increased migration levels would result in greater remittances sent back to the migrant's country of origin. It is understood that increasing remittances would foster development in the sending countries. Since many developing countries are characterized by a chronic shortage of foreign exchange caused by their need to purchase capital goods and energy on world markets, an increase in 
monetary remittances would be a valuable tool for development. Many proponents of open borders argue that remittances provide a form of foreign exchange that is essential to the development and growth of countries in the global South (Taylor et. al., 1996: 189).

A vital element of remittances is that they act as an additional source of income distributed to individuals, households, and communities, which allows for greater freedom to concentrate their activities and to allocate investments to those economic sectors and places that they perceive as most stable and profitable. In this way, remittances may enable households to retreat from, or invest in, local economic activities (De Haas, 2005: 1275). Most studies of remittance use find that remittances are spent on current consumption, health and education leading to improved standards of living for migrant households and higher standards compared to non-migrant households (Keely and Tran, 1989: 505). However, the benefits of remittances tend to be selective. Nyberg-Sorensen, Van Hear, and Engberg-Pedersen (2002) argue that remittances "tend to go to the better-off households within the better-off communities in the better-off countries of the developing world since these households, communities, and countries tend to be the source of migrants." (p.53). This demonstrates that while remittances increase income distribution and quality of life, they do not affect all people equally, and often tend to pass over those individuals or households who have the greatest need for additional income.

Remittances are often praised for the micro-level at which they operate. Yet this is not only their strength, but also their primary weakness. Individual migrants are generally not able to remove larger, macro-level development constraints that affect many people living in the global South (De Haas, 2005: 1279). General development constraints, such as bad infrastructure, corruption, a lack of macroeconomic stability, the absence of appropriate public policies (including schooling, health care, and land reform), market failures, difficult access to 
international markets because of trade barriers, a lack of legal security and a lack of trust in government institutions are all likely to play a constraining role in remittance transfers and may prevent migrant households from taking the risk of investing socially, politically, and financially in their countries of origin and may also lower their desire to return home (De Haas, 2005: 1275). With these larger barriers taken into consideration, it appears that increasing remittances does not automatically result in increasing development.

Development ultimately comes down to responsible governance. Migration is by no means a substitute for responsible governance by governments of the migrant-sending countries (De Haas, 2005: 1279). However, some studies have shown that emigrants have been actively engaged in transnational practices that push for responsible governance in their home countries. Migrant diasporas are engaged transnational practices such as relief, investments, cultural exchange, and political advocacy, which have direct effects on international development cooperation (Nyberg-Sorensen, Van Hear, and Engberg-Pedersen, 2002: 54). Transnational political networks, advocacy, and lobbying practices are not a new phenomenon, but these practices are growing and slowly receiving attention within policy-making circles. Among the reasons for this are sending countries' particular economic incentives to mobilize citizens (and former citizens) abroad. The development of competitive democratic party politics in sending countries, the rise in intra-state conflicts in sending countries, and the increased focus on principles of human rights, democratization and responsible governance have become primary concerns in the foreign policy and donor agenda of major Western states (Nyberg-Sorensen, Van Hear, and Engberg-Pedersen, 2002: 57).

Transnational practices of diasporas demonstrate one way in which migrants are able to sidestep international borders. Increasingly advanced media outlets mean that migrants are able 
to maintain connections with their home country and even remain involved politically and economically within their home country. In an increasingly globalized world we see that it has become ever more simple to maintain transnational identities. Yet when it comes to physical mobility migrants are still restricted from sponsoring their families to join them in their host countries.

Structural factors are also part of the migratory process. Both emigration and immigration countries can become structurally dependent on migration (Delgado-Wise, 2009: 860). Rich countries are the main source of remittances. The United States is by far the largest source, with USD 48.3 billion in recorded outward flows in 2009. Saudi Arabia, Switzerland and Russia are also major sources. In 2010, the top recipient countries of recorded remittances were India, China, Mexico and the Philippines (World Bank, 2011). Taking into account unrecorded flows, the overall amount of remittances surpasses foreign direct investment flows and more than doubled official aid received by countries in the developing world (Delgado-Wise, 2009: 768). According to the International Organization for Migration, remittances have increased exponentially in recent years; from 2000 to 2010 remittances increased from USD 132 billion to an estimated USD 440 billion. This estimate does not include unrecorded flows through formal and informal channels that, if included, would make this number significantly higher (World Bank, 2011). The magnitude of remittances relative to aid can foster a dependency on these flows in many migrant-sending countries. Dependence on emigration, as in countries such as the Philippines, means that migration can become a substitute for development rather than a contribution to it. It can become a long-term structural feature of the economy (Castles, 2004: $860)$. 
This dependency on remittances is problematic as remittances can be unpredictable because demands for labour can vary greatly. Just as remittances can rise rapidly due to strong demands for labour, there can also be a steep drop in remittances due to rapid repatriation when demand for labour decreases (Keely and Tran, 1989: 501). Developing international collaboration to cast aid and migration in complementary roles, and aid in support of mobile livelihoods requires greater interaction between diasporas and development agencies (NybergSorensen, Van Hear, and Engberg-Pederson, 2002: 68).

This section has identified, among other issues, that remittances are not a substitute for responsible governance when it comes to development. Rather, remittances are a product of contemporary neoliberalism. Because remittances are a form of capital there is relative ease in their movement across international borders. While many scholars point to remittances as a lifeline for the poor in the Global South any economic advantage provided by remittances merely masks the underlying factors of neoliberalism that systematically underdevelop countries in the Global South. Allowing for freedom of movement for people alongside the free movement of capital is one way to rectify this inequality. 


\section{CHAPTER 6: RECONSIDERING OPEN BORDERS}

Driven by the sense of "crisis" surrounding migration in the Global North, issues arising from immigration and its consequences are once again moving to the top of the political agenda in throughout the Western world (Zolberg, 2012: 1213). This "crisis" has been framed by the use of alarmist and extremist language including metaphors of flooding, tidal waves, and dams to a routine association of the figure of the migrant with terrorism, lying, and contagious disease put forward by prominent media sources in the developed world (Gill, 2009: 109).

Over generations, borders have been reified as natural extensions of "nationality" even though international borders have only existed for approximately one percent of human history (Wright, 2008: 190). As a product of neoliberalism, the current migration regime constrains the right of free movement of workers in order to secure their exploitation in the name of gains for capital. The asymmetrical relationship between the mobility of workers in the Global South and Global North is a product of the capitalist international segmentation of labor described in the previous sections. Neoliberalism and capitalist restructuring have created a system of global apartheid necessary to secure the demands of global capitalism and serve the needs of national economies in the Global North. This system both produces and is dependent upon the construction of international borders (McDonald, 2009: 73). Consumers in developed nations benefit from the exploitation of workers in the developing world (Bauder, 2003: 173). While workers who move within nation-states are often praised for their entrepreneurial ability, once an individual crosses an international border in search of work they considered criminals and face the threat of incarceration or deportation (Wright, 2008: 190). 
Thus, a common argument put forth against the liberalization of borders is that the resultant volume of migration would be too high for any state to accommodate (Gill, 2009: 110). The idea being that given the huge disparities of wealth characterized in the modern world system, open borders would lead to massive flows of people moving from the Global South to the Global North. As the previous sections of this paper demonstrated, the factors that impel migration are diverse and circumstantial. According to Hayter (2004) most people prefer to stay in their country of origin since there are often economic, linguistic, and cultural barriers to integration abroad.

These results have been reproduced in the experiences of Eastern European migrants following accession to the European Union. It had been predicted that large numbers of migrants would move from Eastern European nations to the more affluent Western European member states given the freedom of movement within these countries. Studies have found that the movement of Eastern European labourers represented only one per cent of the United Kingdom labour market (Gill, 2009: 110). However this finding needs to be qualified as it included only those people officially recognized as seeking work. Less can be said about the unofficial employment rate, which might be affected by the informal and temporary work sector (Gill, 2009: 111). Even in the absence of effective migration controls, there are still a number of reasons to expect migrants to be unable to overcome the numerous barriers to migration in the sending country. In other words, many of the world's poorest populations do not have the means to migrate, even in the absence of controls on migration.

The finding that the majority of people would choose not to migrate if given the choice demonstrates that removing borders altogether will not immediately eliminate global inequality. Rather, any liberalization of international borders can only be considered in the context of other 
political and economic reforms that would allow all people equal opportunity for migration. These reforms begin with a rethinking of the capitalist world system that perpetuates the exploitation of the Global South in order to secure economic prosperity.

\section{Why Open the Borders?}

"Free population movement promises greater human liberties and improved economic performance" (Gill, 2009: 107). If the United Nations Universal Declaration of Human Rights grants the right to migrate as a fundamental and undeniable basic human right, it seems contradictory that the right to immigrate is so restricted. From a human rights and global development perspective, we can only support the free movement of people. However, this assertion depends on the willingness of states to accept universal human rights as a fundamental principle for ordering and evaluating human society (Moses, 2006: 59).

The lines between citizen and foreigner, local and global, national and transnational are rapidly blurring (Munk, 2008: 1239). This paper argues that aside from the moral responsibility to reduce global inequality and promote social justice, the liberalization of borders is necessary in terms of economic efficiency. Borders can be understood as an impediment to the functioning of a free market (Gill, 2009: 107). Economic arguments for open borders demonstrate that various parties gain from migration, including migrants themselves, sending countries, and receiving countries (Gill, 2009: 108). As the previous sections of this paper have demonstrated, remittances do not necessarily benefit sending countries and receiving countries equally. Rather, what this discussion of remittances has demonstrated is how easily capital can be transferred between the frontiers of nations, and yet their human counterparts are unable to cross these borders. Capitalism is served by the immobility of the working class, but could just as well be 
served by its mobility. On a subnational scale, the gains from free movement are evident in the unfettered growth, and decline, of cities as the natural spatial unit of capitalism (Gill, 2009: 112). A reduction in national border controls would allow cities to expand and contract in response to the counterimposed forces of agglomeration and dispersion without being subject to external regulation, thereby achieving a more efficient match between migration supply and demand (Gill, 2009: 112).

Framing the discussion of open borders in terms of solely economic advantages risks the instrumentalization of migrant concerns and the legitimation of the exploitation of people moving from the "developing world", particularly those with professional expertise. With a high number of Western countries facing demographic decline, the developed world is becoming increasingly reliant on imported expertise from the Global South (Gill, 2009: 114). Policies geared toward enhancing the economic advantages of migration overlook the less privileged, working class migrants from the Global South. These migrants are left with little recourse but to rely on the asylum system, temporary visas or risking living with illegal status in the host country (Bauder, 2003: 169).

This raises the question of why the geographical location of an individual's birth has the ability to dictate their life potential and access to labour markets (Wright, 2008: 190). When citizenship is no longer accepted as a moral right from birth, but rather as a lucky outcome of the geographical lottery, then the advantages that are derived from that luck are difficult to defend in moral terms. From a universalistic moral perspective, it is necessary to ask why the rights of freedom, justice and equality are distributed by the arbitrary luck of birth (Moses, 2006: 63). Not only are there severe restrictions on the movement of people from the Global South to the North, but those from the North are able to move with relative ease to the Global South. This is because 
the high-wage expectation of citizens in the Global North means they are not seen as competition for local workers in the South (Bauder, 2003: 174). Western democracies rely upon international trade and tourism, making their borders permeable from the outset, and their long histories of migration render them subject to the momentum that this has created, for example, in terms of the formation of migrant networks. The fact that Western democracies tend to place a high value upon human rights also exposes individual states to humanitarian pressure to relax restrictive border controls (Gill, 2009: 110).

Those who most strongly oppose arguments for open borders are what Gill (2009) refers to as "Right-wing Conservatives" who tend to base their arguments for restricting immigration on the reduction of available jobs for "native" workers, depletion of welfare benefits, and the undermining of a sense of "national identity" (Gill, 2009: 107). However it is exceedingly clear that alarmist attitude of those who advocate for a restriction of immigration controls is unwarranted. Their ideology is based on the fact that open borders are a threat to the existence of the nation state (Bauder, 2003: 170). What this ideology does not question is the broader and more concerning issue of why people so frequently regard the loss of state sovereignty as a bad thing to begin with. 


\section{$\underline{\text { Towards a Universal Treatment of Migrants }}$}

The centrality of the nation-state to formulating neoliberal policies leads to important outcomes surrounding issues of social justice. It leads to the view that rights can only be conceived within a bounded group or entity such as the nation-state. Discussions of justice are therefore confined to national borders. (Zapata-Barrero and Pécoud, 2012: 1159). There are currently no global or multilateral regimes for the governance of migration. The closest approximation can be found in the arena of refugee policy, where the United Nations High Commissioner for Refugees intervenes in order to address refugee crises and coordinates efforts to resettle the nearly 34 million displaced people worldwide (Gordon, 2010: 1121). The international community continues to follow the immigrant/refugee dichotomy, placing people in either category based on outdated international standards. Several groups of internally and externally displaced persons needing assistance and protection have remained inadequately covered under existing international mandates and national practices (Ghosh, 2000: 16). The International Organization for Migration (IOM) has assisted approximately eleven million refugees since its creation but its mission has never been to broker multilateral migration agreements or to establish a platform for regulating migration controls on a global level (Hatton, 2007: 362). It is necessary to note the difficulties of translating ideal policy stances into workable and effective migration policies (Gill, 2009: 110). In the context of migration control, there are intractable limitations upon effective border control management.

The recognition of the normality of the cross-border movements of people leads to a discussion not only of whether borders should be open or closed, but of how migration flows are to be governed in accordance with the principles and values of liberal democratic states (ZapataBarrero and Pécoud, 2012: 1160). An effective international migration regime would require an 
instrument of international law, probably within the UN system, which would advocate and protect the rights of international migrants as well as oversee the adoption of the international legal instrument into international law. This newly created convention should also provide definitions of the groups covered and procedural roles for international governance in the field (Castles, 2004: 876). New venues that enable the world's governments to discuss and debate migration issues directly with each other are emerging. None of these multilateral bodies or processes has produced a single accord to bind participating governments (Gordon, 2010: 1223). Recently, new thinking about enhanced co-operation over migration has been reflected in a number of policy forums, the most notable of which is the United Nations (Hatton, 2007: 342). In the policy arena, the UN-sponsored Global Commission on International Migration called in 2005 for the formation of a UN-based "Inter-agency Global Migration Facility" to "establish a comprehensive and coherent approach in the overall institutional response to international migration" (Gordon, 2010: 1222).

Currently, there is a top-down process for dealing with migration management that has been unsuccessful in resolving current issues. Migration management should be characterized by a cooperative process in which all participants have a voice, including the governments and civil societies of sending countries, the receiving countries, and individual migrants (Castles, 2004: 874). The world badly needs enlightened immigration policies and best practices to be spread and codified (Bhagwati, 2003: 104). In the absence of a harmonized set of norms and principles, each government has to gauge the public feeling and assess the political mood of the electorate before moving cautiously towards a policy stand (Ghosh, 2000: 16). Public opinion regarding immigration fluctuates depending on the strength of the economy. In democratic countries governments must heed public opinion, and some observers see this as the reason why, in the 
developed world, trade has been liberalized more than migration. A World Migration Organization should begin to do that by juxtaposing each nation's entry, exit, and residence policies towards migrants, whether legal or illegal, economic or political, skilled or unskilled. Such a project is well worth putting at the centre of policymakers' concerns (Bhagwati, 2003: 104). 


\section{CHAPTER 7: CONCLUSION}

Although international migration is not a new phenomenon, the changing dynamics of our modern world have put the issue at the forefront of national and international discourse. Yet global migration is often spurred by factors outside the migrant's control. This paper has highlighted the involuntary facet of migration. Most of the research on migration has excluded a variety of actors involved in the origination and perpetuation of migratory flows from data collection, analytical assessment, theoretical construction and public policy formation (Krissman, 2005: 5). Much mainstream migration literature is deeply flawed and generally fails to consider the subjectivities and self-activity of migrants themselves, except as economic units subject to push and pull factors (Wright, 2008: 192). This paper has attempted to shed light on the multiplicity of factors that cause people to migrate, but also that cause people to stay.

By ignoring how people move and how they are legally, socially, economically, and politically positioned by the state within nationalized societies, it becomes impossible to understand a significant component of global imperial relations of social disparities in wealth and power disparities organized through gendered, racialized and classed relations (Sharma, 2006: 124). In order to discuss the politics of open borders it is necessary to highlight how often ignored histories and practices of colonialism, imperialism, and the "capitalist development" of agriculture and its integration into the world market have been included in immigration debates (Wright, 2008: 192).

Campaigns for the liberalization of border controls have begun to emerge in a number of global contexts, calling for the "free movement of all persons". France's sans-papiers have gained global recognition through their fundamental challenge to traditional notions of 
democracy, civil rights, and citizenship. In Canada, mobilization and organization for the support of refugees and non-status migrants is based predominantly in urban locals. The "Open the Borders!" network in Vancouver, Montreal's "Solidarity Across Borders," and the Ontario Coalition against Poverty based in Toronto have done much to raise the national consciousness about campaigns for the protection of international migrants without status. Central to the politics of protection has been a distinctive rise in the creation of "sanctuary zones" in churches or otherwise resisting the expulsion of non-status migrants. However, as McDonald (2009) argues, campaigns that focus their arguments on a demand for regularization of illegal migrants in Canada, without challenging the regular practices of citizenship in Canada unintentionally reinforce state power (p.65). While programs that push for the regularization of irregular migrants demonstrate an emerging concern for the right of migrants it is only through a discussion of open borders that we may begin to contest citizenship. Immigrant right's advocates have sought to change the policies and practices of the immigration system within Canada as demonstrated in regard to regularization programs (McDonald, 2009: 73).

A fundamental reorientation of the immigration system is necessary. It is commonplace for "civilization" to be equated with Western capitalism, and the drive to universalize that ideology has intensified the idea of progress that is inextricably linked to contemporary capitalism (Bush, 2007: xiii). It is necessary for contemporary policy makers to dispute this ideology. This, of course is a bigger challenge because policy makers are prone to safeguarding the status quo, and to buttress the system. Thus, the open borders idea needs to have a longerterm horizon. Despite its radical nature, an open borders lobby requires an anti-capitalist, antistatist and anti-nationalist viewpoint in order to be successful. 


\section{LIST OF REFERENCES}

Amin-Khan, T. (2012). The Post-Colonial State in the Era of Capitalist Globalization: Historical, Political and Theoretical Approaches to State Formation. New York: Routledge.

Anderson, B. (2010). Migration, Immigration Controls and the Fashioning of Precarious Workers. Work, Employment and Society. 24(2), 300-317.

Anderson, B., Sharma, N., and Wright, C. (2009). Why No Borders? Refuge. 26(2), 5-18.

Ashutosh, I., and Mountz, A. (2011). Migration Management for the Benefit of Whom? Interrogating the Work of the International Organization for Migration. Citizenship Studies. 15(1), 21-38.

Arango, J. (2000). Explaining Migration: A Critical View. International Social Science Journal. 52(165), 283-296.

Baldwin-Edwards, M. (2008). Towards a Theory of Illegal Migration: Historical and Structural Components. Third World Quarterly. 29(7), 1449-1459.

Bartram, D. (2010). International Migration, Open Borders Debates, and Happiness. International Studies Review, 12(1), 339-361.

Bauder, H. (2003). Equality, Justice, and the Problem of the International Borders: The Case of Canadian Immigration Regulaltion. ACME. 2(2), 167-182.

Bauder, H. (2001). Culture in the Labor Market: Segmentation Theory and Perspectives of Place. Progress in Human Geography. 25(1), 37-52.

Bhagwati, J. (2003). Borders Beyond Control. Foreign Affairs. 82(1), 98-104.

Bush, R. (2007). Poverty and Neoliberalism. London: Pluto Press

Carens, J. (1999). Reconsidering Open Borders. International Migration Review. 33(1), 10821097.

Carens, J. (1987). Aliens and Citizens: The Case for Open Borders. The Review of Politics. $49(2), 251-273$.

Carroll, W. (2004). Unpacking and Contextualizing Critical Research Strategies. In W.K. Carroll (Ed.), Critical Strategies for Social Research (1-15) Toronto, ON: Canadian Scholars' Press Inc.

Castles, S. (2004). The Factors that Make and Unmake Migration Policies. International 
Migration Review. 38(3), 852-884.

Clemens, M. (2011, September 5). A World Without Borders Makes Economic Sense: Allowing Workers to Change Location Significantly Enriches the World Economy. The Guardian. http://www.guardian.co.uk/global-development/poverty-matters/2011/sep/05/migrationincrease-global-economy

De Hass, H. (2005). International Migration, Remittances and Development: Myths and Facts. Third World Quarterly. 26(8), 1269-1284.

Delgado Wise, R. (2009). Forced Migration and US Imperialism: The Dialectic of Migration and Development. Critical Sociology. 35(6), 767-784.

Dowty, A. (1987). Closed Borders: The Contemporary Assault on Freedom of Movement. London: Yale University Press.

Fernandez-Kelly, P., and Massey, D. (2007). Borders for Whom? The Role of NAFTA in Mexico-U.S. Migration. The ANNALS of the American Academy of Political and Social Science. 610(98), 98-118.

Ghosh, B. (2000). Towards a New International Regime for Orderly Movements of People. In B. Ghosh (Ed.), Managing Migration: Time for a New International Regime? (6-26) Oxford, UK: Oxford University Press.

Gill, N. (2009). Whose "No Borders"? Achieving Border Liberalization for the Right Reasons. Refuge. 26(2), 107-120.

Gordon, J. (2010). People are not Bananas: How Immigration Differs from Trade. Northwestern University Law Review. 104(3), 1109-1145.

Hall, T., and Kardulias, P. N. (2010). Human Migration over Millenia: A World-Systems View of Human Migration, Past and Present. In T. Jones and E. Mielants (Eds.), Mass Migration in the World System: Past, Present, and Future (22-37). Boulder, CO: Paradigm Publishers.

Hansen, K. (2009). Postmodern Border Insecurity. Administrative Theory \& Praxis. 31(3), 340-359.

Harvey, D. (2006). Spaces of Global Capitalism: Towards A Theory of Uneven Geographical Development. New York, NY: Verso.

Hatton, T. (2007). Should we have a WTO for International Migration? Economic Policy. 22(50), 339-383.

Hayter, T. (2004). Open Borders: The Case Against Immigration Controls. $\left(2^{\text {nd }}\right.$ Ed.). London: Pluto Press. 
Hayter, T. (2001). Open Borders: The Case Against Immigration Controls. Capital \& Class, 75(1), 149-156.

Henn, M., Weinstrin, M., and Foard, N. (2009). A Critical Introduction to Social Research. London: SAGE Publications Ltd.

Higgins, P. (2008). Open Borders and the Right to Immigration. Human Rights Review. 9(4), 525-535.

Huemer, M. (2010). Is There a Right to Immigrate? Social Theory and Practice. 36(3), 429-461.

Johnson, K. (2003). Open Borders? UCLA Law Review. 51(1), 193-263.

Keely, C., and Tran B.N. (1989). Remittances from Labor Migration: Evaluations, Performance and Implications. International Migration Review. 23(3), 500-525.

Kirby, S. and McKenna, K. (2004). Methods from the Margins. In W.K. Carroll (Ed.), Critical Strategies for Social Research (64-74) Toronto, ON: Canadian Scholars' Press Inc.

Krissman, F. (2005). Sin Coyote Ni Patron: Why The "Migrant Network" Fails to Explain International Migration. International Migration Review. 39(1), 4-44.

Kukathas, C. (2011). Expatriatism: The Theory and Practice of Open Borders. In R.M. Smith (Ed.). Citizenship, Borders, and Human Needs (324-342). Philadelphia, PA: University of Pennsylvania Press.

LeGrain, P. (2009, March 1). Open Borders. The Future of Freedom Foundation. Retreived from http://fff.org/explore-freedom/article/open-borders-work-part-1/

Lenard, P. (2010). Culture, Free Movement, and Open Borders. The Review of Politics. 71(1), 627-652.

Lowry, M. (2002). Creating Human Insecurity: The National Security Focus in Canada's Immigration System. Refuge. 21(1), 28-39.

Malkki, L. (1994). Citizens of Humanity: Internationalism and the Imagined Community of Nations. Diaspora: A Journal of Transnational Studies. 3(1), 41-68.

Marchand, M. (2008). The Violence of Development and the Migration/Insecurities Nexus: Labor Migration in a North American Context. Third World Quarterly. 29(7), 1375-1388.

Massey, D., Arango, G.H., Kouaouci, A., Pellegrino, A., and Taylor, J.E. (1993). Theories of International Migration: A Review and Appraisal. Population and Development Review. 19(3), 431-466. 
McDonald, J. (2009). Migrant Illegality, Nation-building, and the Politics of Regularization in Canada. Refuge. 26(2), 65-77.

Moses, J. (2006). International Migration: Globalization's Last Frontier. London, UK: Zed Books.

Munk, R. (2012). Migration, Development and Work in the Global Order: A New Perspective. Journal of Latino/Latin American Studies. 4(1), 42-56.

Munk, R. (2008). Globalization, Governance and Migration: an Introduction. Third World Quarterly. 29(7), 122-1246.

Ness, I. (2007). Forging a Migration Policy for Capital: Labor Shortages and Guest Workers. New Political Science. 29(4), 429-452.

Nyberg-Sorenson, N., Van Hear, N., and Engberg-Pedersen, P. (2002). The MigrationDevelopment Nexus: Evidence and Policy Options. International Migration. 40(5), 4973.

O'Brien, R. and Williams, M. (2007). Global Political Economy: Evolution and Dynamics. $\left(2^{\text {nd }}\right.$ Ed.). New York, NY: Palgrave Macmillan.

Papademetriou, D. (2011). International Migration: Global Trends and Issues. In R.M. Smith (Ed.), Citizenship, Borders, and Human Needs (13-36). Philadelphia, PA: University of Pennsylvania Press.

Portes, A. (1978). Toward a Structural Analysis of Illegal (Undocumented) Immigration. International Migration Review. 12(4), 469-484.

Rodney, W. (1982). How Europe Underdeveloped Africa. Washington, DC: Howard University Press.

Sassen, S. (2011). Global Migrations and Economic Need. In R.M. Smith (Ed.). Citizenship, Borders, and Human Needs (56-91). Philadelphia, PA: University of Pennsylvania Press.

Seglow, J. (2005). Immigration, Sovereignty, and Open Borders: Fortress Europe and Beyond. Review of Constitutional Studies. 10(1), 111-134.

Sharma, N. (2006). White Nationalism, Illegality and Imperialism: Border Controls as Ideology. In K. Hunt and K. Rygiel (Eds.). (En)Gendering the War on Terror. (121-143). Aldershot, UK: Ashgate Publishers.

Taylor, J., Arango, J., Hugo, G., Kouaouci, A., Massey, D., and Pellegrino, A. (1996). International Migration and National Development. Population Index. 62(2), 181-212.

United Nations, Department of Economic and Social Affairs, Population Division (2009). Trends 
in International Migrant Stock: The 2008 Revision (United Nations database, $\mathrm{POP} / \mathrm{DB} / \mathrm{MIG} / \mathrm{Stock} / \mathrm{Rev} .2008$ ).

Waltzer, M., (1984). Spheres of Justice: A Defense of Pluralism and Equality. New York: Basic Books.

World Bank's Migration and Remittances Factbook 2011, http://go.worldbank.org/QGUCPJTOR0

Worrel, E. (2009). Free Trade, Free Migration: A Path to Open Borders and Economic Justice in the North American Free Trade Agreement. Temple International and Comparative Law Journal. 23(1), 113-??

Wright, C. (2008). Challenging States of Illegality: From "Managed Migration" to a Politics of No Borders. Labour. 62(1), 185-198.

Zapata-Barrero, R., and Pécoud, A. (2012). New Perspectives on the Ethics of International Migration. American Behavioral Scientist. 56(9), 115-1164.

Zolberg, A. Why Not the Whole World? Ethical Dilemmas of Immigration Policy. American Behavioral Scientist. 56(9). 1204-1222.

Zolberg, A. The Next Waves: Migration Theory for a Changing World. International Migration Review. 23(3), 403-430. 